\title{
Macroinvertebrate functional organization and water quality in a large arid river from Patagonia (Argentina)
}

\author{
M.L. Miserendino \\ LIESA. Laboratorio de Investigaciones en Ecología y Sistemática Animal, Universidad Nacional de la Patagonia, Sarmiento 849, 9200 Esquel, \\ Chubut, Argentina. E-mail: 1miserendino@liesa.org.ar
}

The composition and abundance of functional feeding groups of the macroinvertebrate communities were investigated along the Chubut River in the Patagonian Precordillera and Plateau, Argentina. Chubut River $(>1000 \mathrm{~km})$ is the largest river in the area and the hydrological regime is modified in the lower section by an artificial reservoir (Florentino Ameghino Dam). Quantitative benthic samples were collected at 13 sites in the upper, middle and lower sections of the river basin. Sites were visited four times during 2004 and physicochemical parameters, chlorophyll $a$ and particulate organic matter (POM) were assessed. In terms of relative abundance, collector-gatherers and scrapers/grazers were the predominant groups at most sites. Shredders were not abundant in the upper sites and were practically absent at middle and lower basin sites. Collector filterers that comprised more than $25 \%$ of abundance at the pre-regulated site were practically absent right below the dam. POM biomass decreased significantly with distance from the source and chlorophyll $a$ showed a marked increase below the reservoir. We conclude that although there was a distinct headwaters fauna in the Chubut River, and sequential downstream changes in species composition, most functional feeding groups (apart from shredders) were represented down the whole length of the river. Finally, the usefulness of biotic indices and metrics in relation with main environmental features of the Chubut River basin is discussed.

Keywords: functional feeding groups, detritus, chlorophyll, river, spatial variation.

\section{Introduction}

Community structure of benthic invertebrates in rivers change both spatially and temporally, largely in relation to environmental factors (Allan 1995, Poff \& Ward 1990, Bretschko 1995). Flow, substratum, temperature, water chemistry, aquatic plants, food, and biotic interactions rule community composition and structure (Armitage 1984, Ward 1992). Riparian vegetation plays a crucial role in determining the productivity and trophic relationships of stream ecosystems (Cummins et al. 1989), and the relative abundance of allochthonous and autochthonous organic matter in running waters can be expected to determine the distribution and abundance patterns of invertebrate functional feeding groups (Vannote et al. 1980). The functional structure along streams in Patagonia mountains seems to correspond well with the predictions of the RCC (River Continuum Concept) with biomass of shredders decreasing and collector biomass increasing downstream from the headwaters (Miserendino \& Pizzolón 2000). However, less known are the functional organizations of benthic communities and their environmental relationships in large arid rivers as those in the Patagonian Plateau (Miserendino 2004).
In the Chubut Province, from the mountain to the Atlantic Ocean, and along the same latitude, ecoregions range from temperate rainforests in the Patagonia Mountains to the herbaceous steppes in the arid and semiarid Plateau. The Chubut River is the largest and longest $(>1000 \mathrm{~km})$ watercourse associated to this area and has an extensive altitudinal $(1000 \mathrm{~m})$ gradient. The basin has contrasting features in climate (primarily rain), geology, riparian vegetation and land uses. Furthermore, the basin sustains multiple activities, which include agriculture, cattle-raising and irrigation, and the river is regulated in the lower section (Coronato \& Del Valle 1988, Sastre et al. 1997, Luque et al. 2000). For more than a century irresponsible land use in the middle and lower Chubut River basin also resulted in severe desertification (del Valle et al. 1995, 1998).

To date, most of the research on benthic invertebrate communities in Patagonia (Argentina) has been done in streams and rivers of the Cordillera Mountains (Miserendino \& Pizzolón 2003, 2004). Little is known about benthic communities from continental rivers in the Plateau (Miserendino 2006). There is also very little known about benthic communities and benthic organic matter availability of large river in arid areas (Wais 1990, Stevens et al. 
1997, Francis \& Sheldon 2002, Pettit et al. 2006). Biological studies in large rivers are uncommon due to difficulty of working in them, their size and complexity, long distances and the effort required (Beauger et al. 2006). The present paper reports the results of a seasonal study in the Chubut river basin whose main aims were (1) to describe functional organization of macroinvertebrate communities and physicochemical parameters, and (2) to assess water quality and the use of several invertebrate biotic indices for biomonitoring in a large arid Patagonian river.

\section{Methods and materials}

\section{Study area}

The Chubut River flows from west to east through the Patagonian ecoregion and drains into the Atlantic Ocean (Fig. 1). Its basin $\left(25,225 \mathrm{~km}^{2}\right)$ is located in two main biozones: the Extra-Andean Oriental and ExtraAndean Occidental (Del Valle et al. 1995, Paruelo et al. 1999). Geomorphologic features and local climatic characteristics divide the basin into three parts. The upper basin $\left(7,000 \mathrm{~km}^{2}\right)$ is characterized by a strong westeast rainfall gradient (500-100 $\left.\mathrm{mm} \mathrm{y}^{-1}\right)$ and being near the cordillera has the lowest temperature (mean annual air temperature $\left.8.5^{\circ} \mathrm{C}\right)$. The middle basin $\left(12,000 \mathrm{~km}^{2}\right)$ has an average rainfall of $150 \mathrm{~mm} \mathrm{y}^{-1}$ and mean annual temperature of $13.2^{\circ} \mathrm{C}$. The lower basin, the regulated section of the river, has the smallest area $\left(6,000 \mathrm{~km}^{2}\right)$ and rainfall of $150 \mathrm{~mm} \mathrm{y}^{-1}$ (Coronato \& del Valle 1988). Dominant soils in the basin are aridisols, entisols and vertisols (del Valle et al. 1998), all of which are characteristic of arid and semiarid Patagonia. Most of the Chubut River is on the Patagonian Steppe, where the low precipitation has resulted in xerophytic, herbaceous-shrub-like steppe vegetation that includes Mulinum spinosum, Stipa spp., Senecio filaginoides, Colletia spinosissima, Adesmia campestris, Fabiana imbricata and Chuquiraga avellanedae (Tell et al. 1997). In several parts of the upper and middle basins, the riparian corridor consists solely of the exotic willow, Salix fragilis, but in some lower sections the native willow $S$. humboldtiana is also present.

Land use adjacent to the river is mainly agricultural, with extensive livestock grazing in the upper and middle sections, and mainly smaller farms and industries in the lower section. In the middle basin, anthropogenic activities in the last century (overgrazing, wood collection) have accelerated land cover degradation, including desertification that ranges from moderate to very severe (del Valle et al. 1998). Recently, landowners have started to cultivate potatoes, corn, and alfalfa

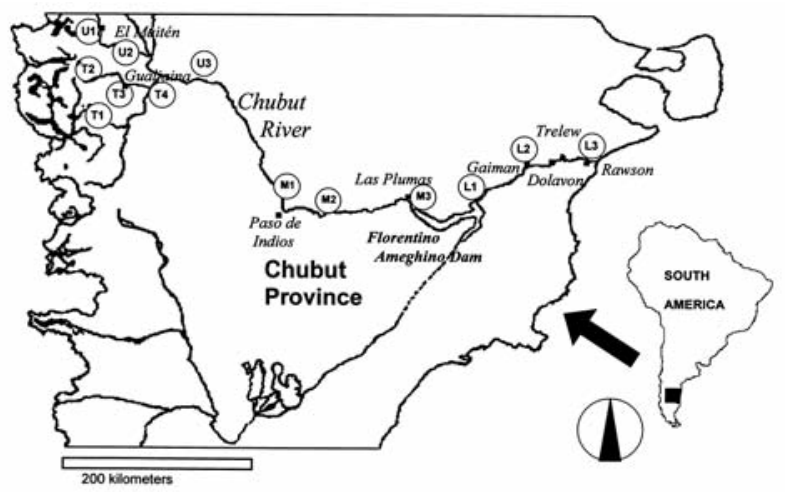

Fig. 1. Map showing the locations of the 13 sampling sites in the Chubut River, Patagonia Argentina. Names of the sites are in Table 1 .

on this low-productivity land, and water is taken from various segments of the river for irrigation. However, no fertilizers or herbicides are used on crops and water returns to the river by natural gravity (Luque et al. 2000). Cities along the river in the lower basin take potable and irrigation water from the Florentino Ameghino Dam $\left(74 \mathrm{~km}^{2}\right)$ via a network of channels in the lower valley. The three largest cities, Gaiman, Trelew and Rawson together have more than 250,000 inhabitants.

\section{Sampling sites}

Thirteen sampling sites were established within the river system (Fig. 1). T1 (Madera Stream) and T2 (Lepá River) were located on upper tributaries, U1 was on the Chubut River alongside El Maitén (3,500 inhabitants) and U2 was on the Chubut River further downstream. T3 (Lepá River) was located alongside Gualjaina City $(1,000$ inhabitants) and T4 was further downstream where the Gualjaina River joins the Lepá River. To assess possible changes in the river fauna in response to land use in the upper and middle basin, four sites (U3, M1, M2 and M3) were selected in the Chubut main channel. Finally, M3 was established next to the rural town of Las Plumas (500 inhabitants), L1 was sited $1 \mathrm{~km}$ below Florentino Ameghino Dam and L2 and L3 were located in the more developed and urbanized lower Chubut River basin.

\section{Macroinvertebrate collection and functional feeding groups:}

All 13 sites were sampled in February, May, September and December 2004. Three macroinvertebrate samples were taken from run/riffles at each site with a modified kick-net sampler (frame area $0.25 \mathrm{~m}^{2}, 250 \mu \mathrm{m}$ 
pore size) (Hauer \& Resh 1996). Samples were fixed in a $4 \%$ formaldehyde solution and were sorted under $5 x$ magnification before being stored in $70 \%$ ethyl alcohol. Species were identified using available keys (Lopretto \& Tell 1995, Fernández \& Domínguez 2001). Functional feeding groups were assigned by gut analyses (10 individuals/taxon/site) under microscope with addition of glycerin, knowledge of feeding modes (mouthpart morphology and behavior), and using available references (Merritt \& Cummins 1996, Domínguez 1998, Miserendino \& Pizzolón, 2000, Velásquez \& Miserendino, 2003).

\section{Biotic Indices}

Indices employed in the study included qualitative and quantitative data. Shannon Weaver diversity index was calculated as a measure of community structure. Two biotic indices for rapid assessment IAP (genus level) and BMPS (familiy level) (Miserendino \& Pizzolón 1999; Pizzolón \& Miserendino 2001) were also employed. These indices have been found to be useful to discriminate environmental impacts in rivers and streams in the Cordillera and Precordillera in Patagonia. Mean monthly species richness and EPT taxa index were also obtained.

\section{Environmental variables}

Percentages of boulder, cobble, gravel, pebble, and sand in run/riffles were estimated at each site using a $1-\mathrm{m}^{2}$ grid (Gordon et al. 1994). Stream order was obtained from Coronato \& Del Valle (1988). Average depth was calculated from five measurements taken on a transect across the channel. Surface current speed was obtained by timing a bobber (average of 3 releases) over a distance of 10 metres (Gordon et al. 1994). Air and water temperature were measured with a mercury thermometer $\left(-10 /+60^{\circ} \mathrm{C}\right)$ on each occasion, and daily discharge data for the Chubut River (U1, U3, M2, M3, L2, L1) and its tributaries (T3, T4) were kindly provided by the Secretaría de Recursos Hídricos de la Nación.

Water samples were collected below the surface and kept at $4^{\circ} \mathrm{C}$ prior to analysis (each site $n=4$ ). Specific conductance, $\mathrm{pH}$, total alkalinity, total suspended solids (TSS), and selected nutrients were analyzed in the laboratory. Specific conductance was measured with a Horiba U2-probe, and $\mathrm{pH}$ with an ORION 720 SA meter, both at $20^{\circ} \mathrm{C}$. Total alkalinity was determined by acid titration with a colorimetric end-point. Total nitrogen (TN) and total phosphorus (TP) were determined on unfiltered samples digested with persulphate, whe- reas nitrate plus nitrite nitrogen $\left(\mathrm{NO}_{3}+\mathrm{NO}_{2}\right)$, ammonia $\left(\mathrm{NH}_{4}\right)$, and soluble reactive phosphate (SRP) were analyzed on filtered samples using standard methods (APHA 1994).

In the laboratory, samples were elutriated. Particulate organic matter in each benthic sample was separated by sieving (pore size $250 \mu \mathrm{m}$ ), dried at $60^{\circ} \mathrm{C}$ for 24 $\mathrm{h}$ and weighed. Since all organic detritus was collected from the streambed the term particulate organic matter (POM) is used for total detritus (i.e., FPOM plus CPOM) (Voelz \& Ward 1990, Miserendino 2004).

Algal biomass (as chlorophyll $a$ ) was determined by scraping algae from five randomly selected rocks (length range: $5-16 \mathrm{~cm}$ ) collected within a $20 \mathrm{~m}$ run/riffle reach at each site. Scrapings were kept dark and on ice in $120 \mathrm{ml}$ water for up to 3 days before they were brought back to the laboratory and drawn on to $\mathrm{GF} / \mathrm{FF}$ filters. Chlorophyll $a$ was extracted from pulverized filters in $90 \%$ acetone and the extract was measured, spectrophotometrically as described by Wetzel \& Likens (1991).

\section{Data analysis}

Regression analysis was used to examine relationships between the mass of benthic organic matter and chlorophyll $a$ (dependent variables) and distance from the source $(\mathrm{km})$. Dependent variables were $\log$ $(x+1)$ transformed and the quadratic term was included in regressions to test for possible curvilinearity response.

Redundancy analysis (RDA) was conducted to determine the linear combinations of environmental variables that best explained patterns in functional feeding group abundances. RDA was chosen for ordinations because preliminary analysis showed that FFG variation was better described by linear response modeling than by unimodal models (ter Brak \& Smilauer 1998). Ordinations were performed using the package CANOCO version 4.0 (ter Brak 1998). Biotic variables were $\log (\mathrm{X}+1)$ transformed prior to statistical analysis to normalize and stabilize variance. To extract a reduced variable set, covariable environmental factors were excluded if the VIF (variable inflation factor) was $>10$ (ter Braak \& Smilauer 1998). A set of 6 environmental variables was used to perform the definitive RDA analysis.

To assess the response of metrics and indices to environmental conditions the Pearson product-moment correlations with Bonferroni adjustment were calculated (Sokal \& Rohlf 1995). 
Table 1. Environmental features, detritus and autochthonous production measured at 13 sampling sites on the Chubut River basin, Patagonia, Argentina. Mean values \pm SD $(n=4)$. T; tributary, Ch: Chubut main channel. U: Upper basin, M: middle basin, L: lower basin. B: boulder, C: cobble, P: pebble G: gravel, S: sand, c: coarse, f: fine. Land use codes: Cr: cattle raising, Ur: urban, A: agriculture, R: flow regulation.

\begin{tabular}{|c|c|c|c|c|c|c|c|c|c|c|c|}
\hline 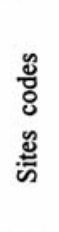 & 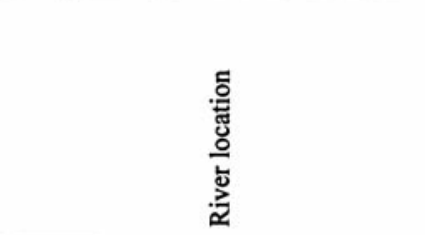 & 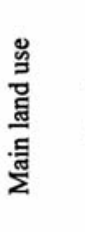 & 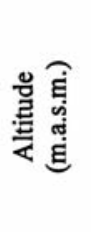 & 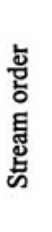 & 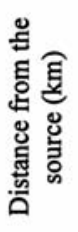 & 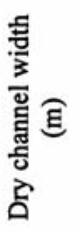 & 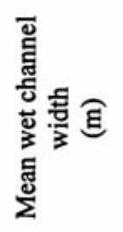 & 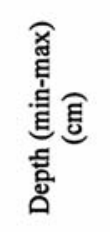 & 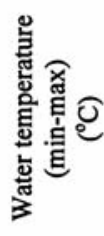 & 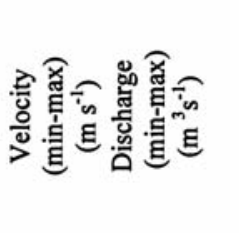 & 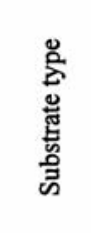 \\
\hline T1 & Madera Stream & $\mathrm{Cr}$ & 936 & 3 & 24.5 & 12 & $8.5 \pm 8$ & $8-19.2$ & $4.5-20$ & $0.3-1.7 \quad 0.09-2.7$ & $\mathrm{C} / \mathrm{P}$ \\
\hline $\mathrm{T} 2$ & Lepa River & $\mathrm{Cr}$ & 829 & 4 & 27 & 20 & $2.7 \pm 3$ & $17-40$ & $5-20$ & $0.2-1.2$ & $\mathrm{~B} / \mathrm{C}$ \\
\hline U1 & Ch, El Maitén & Ur & 702 & 4 & 67 & 100 & $51.7 \pm 39$ & $38-45$ & $5-17$ & $1.2-1.7 \quad 3.5-239$ & $\mathrm{C} / \mathrm{P}$ \\
\hline U2 & Ch, Fofo Cahuel & $\mathrm{Cr}$ & 500 & 4 & 158 & 80 & $52.5 \pm 24$ & $36.6-45$ & $8-21.4$ & $1.1-2.1 \quad 3.4-239$ & $\mathrm{P} / \mathrm{G}$ \\
\hline $\mathrm{T} 3$ & Lepa River, Gualjaina & $\mathrm{Ur}$ & 518 & 5 & 76.1 & 100 & $32.4 \pm 20$ & $27.2-45$ & $9-21$ & $0.3-1.6 \quad 0.05-96.6$ & $\mathrm{P} / \mathrm{G}$ \\
\hline $\mathrm{T} 4$ & Gualjaina River, After Gualjaina & $\mathrm{Cr}$ & 476 & 6 & 90 & 50 & $30.5 \pm 16$ & $32.8-45$ & $7-22.2$ & $1-1.4 \quad 2.6-234.3$ & P/G \\
\hline U3 & Ch, Piedra Parada & $\mathrm{Cr}$ & 440 & 5 & 208 & 200 & $105 \pm 65$ & $45-53.7$ & $7-21.4$ & $0.9-1.2 \quad 10.2-773$ & $\mathrm{C} / \mathrm{P}$ \\
\hline M1 & Ch, Paso Berwyn & $\mathrm{Cr} / \mathrm{A}$ & 308 & 5 & 394 & 160 & $125 \pm 56$ & $23-45$ & $6-21.4$ & $0.5-1.6 \quad 10.2-773$ & $\mathrm{C} / \mathrm{P} / \mathrm{S}$ \\
\hline M2 & Ch, Los Altares & $\mathrm{Cr} / \mathrm{A}$ & 243 & 6 & 480 & 200 & $117 \pm 58$ & $30-45$ & $7-21.6$ & $0.8-1.2 \quad 6.5-841.2$ & $\mathrm{P} / \mathrm{G} / \mathrm{S}$ \\
\hline M3 & $\mathrm{Ch}$, Las Plumas & $\mathrm{Ur}$ & 158 & 6 & 583 & 300 & $215 \pm 23$ & $19.6-45$ & $7-20.7$ & $1.7-1.96 .5-841.2$ & $\mathrm{~B} / \mathrm{C}$ \\
\hline L1 & Ch, D. F. Ameghino & $\mathrm{R}$ & 74 & 6 & 686 & 70 & $64 \pm 5$ & $45-60$ & $8-15.5$ & $0.7-0.9 \quad 4.8-119.7$ & $\mathrm{C} / \mathrm{P}$ \\
\hline L2 & Ch, 28 de Julio & R-Ur & 32 & 6 & 737 & 40 & $35 \pm 4$ & $46.7-60$ & $8-18.1$ & $0.9-1.4$ & cG \\
\hline L3 & Ch, Estuario & $\mathrm{Ur}$ & 4 & 6 & 838 & 160 & $151 \pm 2$ & $33-60$ & $9-21.1$ & $0.8-1.1$ & $\mathrm{fG} / \mathrm{S}$ \\
\hline
\end{tabular}

\section{Results}

\section{Environmental features of the Chubut River}

River order ranged from 3 to 6 and elevation of the sites was between 4 and $936 \mathrm{~m}$ a.s.l. Substratum size was similar at most sites, and consisted mainly of boulders, cobbles, and pebbles (Table 1). Sites M1, M2, and L3 had a higher percentage of sand than the other sites. Monthly water temperature patterns (Table 1) show a clear discontinuity in the thermal gradient at $\mathrm{L} 1$, immediately below the dam, where temperature was $5^{\circ} \mathrm{C}$ lower than at M3 in February and December.

Maximum current velocity $\left(2.1 \mathrm{~m} \mathrm{~s}^{-1}\right)$ was recorded at $\mathrm{U} 2$ in February and the minimum $\left(0.2 \mathrm{~m} \mathrm{~s}^{-1}\right)$ was recorded at $\mathrm{T} 2$ in summer when water was being abstracted for irrigation (Table 1). Discharge showed an exceptionally high peak in the main channel of the upper and middle sections of the Chubut as a consequence of strong rains in July. Flow decreased in the lower basin below Florentino Ameghino Dam (L1 and L2).
Chemical and physical data provided a clear distinction between the upper catchments sites and those in the middle and lower catchments (Fig. 2). Conductivity in the middle basin was $141-275 \mu \mathrm{S} \mathrm{cm}^{-1}$, whereas in the lower basin it reached $2960 \mu \mathrm{S} \mathrm{cm}^{-1}$. TSS values were higher in the middle basin (40.1- $88.6 \mathrm{mg} / \mathrm{l})$ and at the lowermost site L3 than elsewhere. However, an increase in TSS values was observed at the Chubut main channel sites, starting at U2 (Fig. 2), near the point where the Fita-Michi River flows into the Chubut from the north. Parent rocks in this section (Collon Cura formation; Ardolino et al. 1999) are dominated by friable tuffs, which provide a source of clay sediments when in contact with water. Mean values of TN ranged from 201 to $258 \mu \mathrm{g} \mathrm{l}^{-1}$ at middle basin sites, although values were highly variable. Mean values of $\mathrm{NH}_{4}$ (24.5-35.7 $\left.\mu \mathrm{g} \mathrm{l}^{-1}\right)$ and TP (54.3-84.3 $\left.\mu \mathrm{g}^{-1}\right)$ at middle basin sites were 2-3 fold higher than at upper basin sites, and may have been related to the presence of livestock and agricultural activities in that section of the river. The highest values of $\mathrm{NH}_{4}$ and $\mathrm{NO}_{3}$ were obtai- 

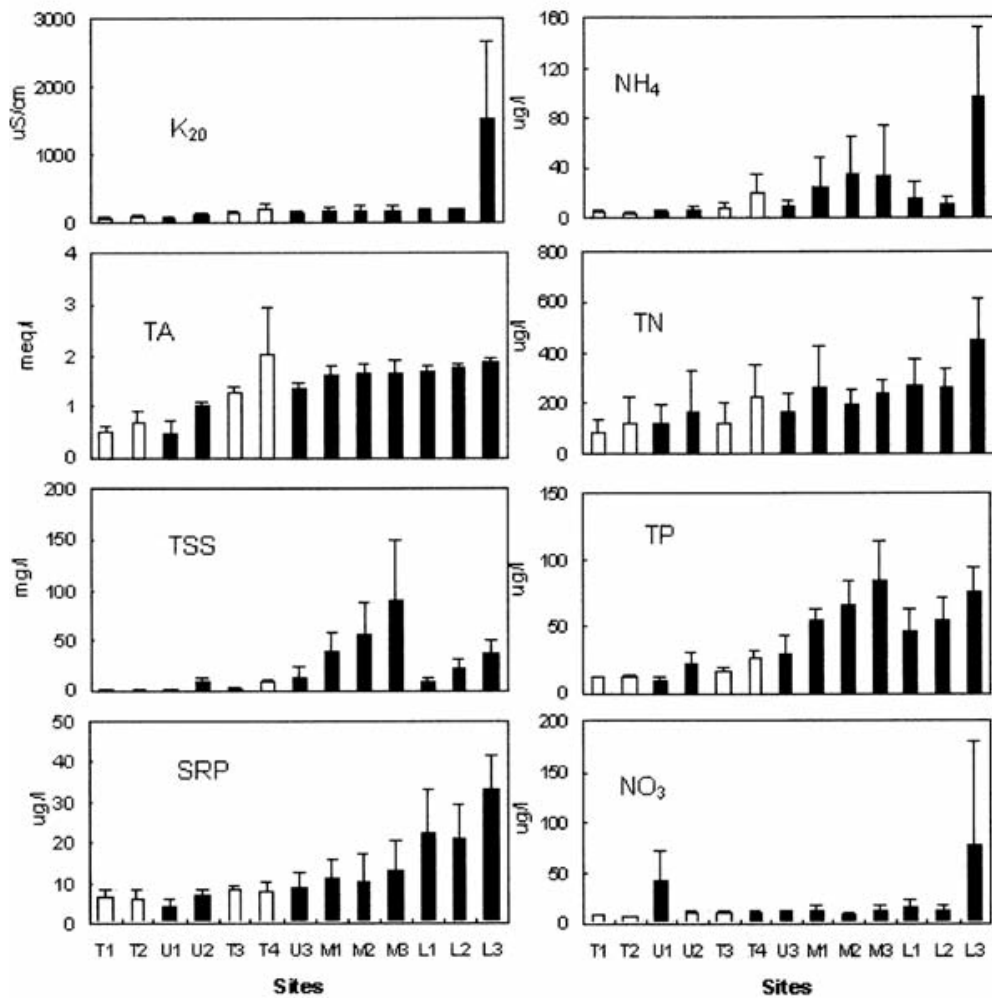

Fig. 2. Mean values $( \pm \mathrm{SD})$ of the chemical variables in 13 sampling sites of the Chubut River basin, Patagonia, Argentina, during $2004(n=4)$. Open bars: tributaries, dark bars: main channel sites. K20: conductivity, TA: total alkalinity, TSS: total suspended solids, SRP: soluble reactive phosphorus, NH4: ammonia, TN: total nitrogen, TP: total phosphorus, NO3: nitrate plus nitrite nitrogen.

ned at L3, and probably reflected the presence of important industrial and urban development in the area (Fig. 2).

\section{Benthic organic matter, chlorophyll $a$}

The dry weight of detrital material taken in benthic samples during the study period ranged between 0 to $27.3 \mathrm{~g} . \mathrm{m}^{-2}$ (Fig. 3). Biomass was low in T3, M2 and in the lower basin sites. At most sites POM biomass was lower during February than other dates. A significant relationship between particulate organic matter and distance from the source was observed ( $<<0.03$, Fig. 4). Maximum values of chlorophyll $a$ were recorded at L1 and L3. Mean values of chlorophyll $a$ increased with distance from the source, but the regression model obtained was not significant $(\mathrm{p}<0.07)$.

\section{Functional organization}

Of the 94 taxa recorded in the entire study, five were shredders, 31 were grazers or scrapers, 26 were collec-
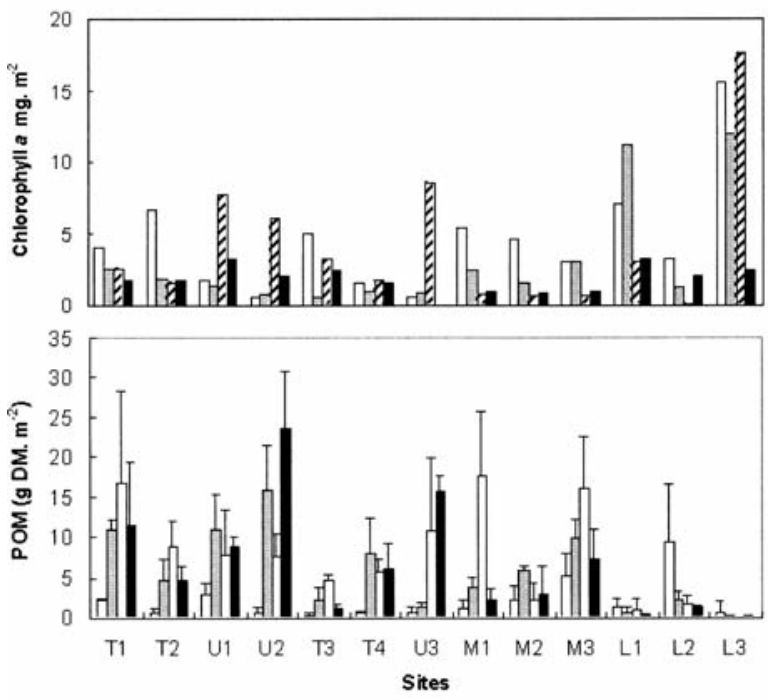

Fig. 3. Seasonal variation of chlorophyll a and benthic particulate organic matter $( \pm \mathrm{SD})$ in riffle areas $(\mathrm{n}=3)$ in 13 sampling sites of upper, middle and lower Chubut River basin. 

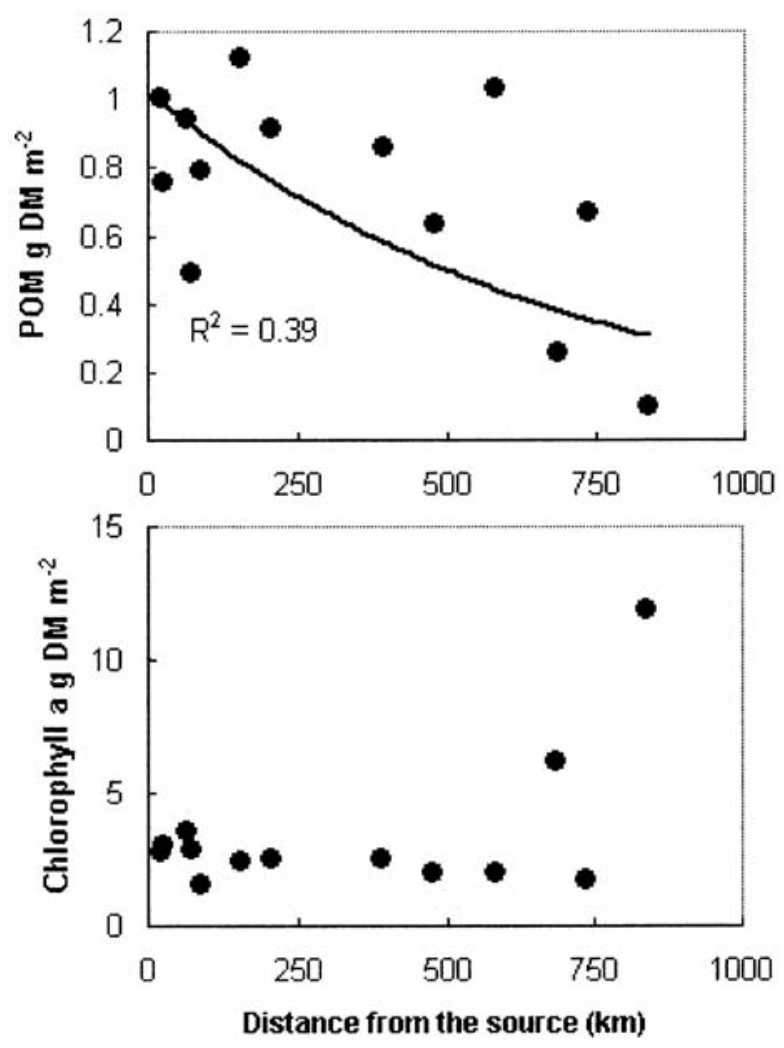

Fig. 4. Mean values of organic matter distribution $(\log +1)(\mathrm{DM} g \mathrm{~g}-$ 2) and chlorophyll a $\left(\mathrm{g} \mathrm{m}^{-2}\right)$ plotted against distance from the river source. Coefficient values $\left(\mathrm{r}^{2}\right)$ for significant regressions $(\mathrm{p}<0.01)$ are shown.

tor gatherers, 6 were collector filterers and 25 were predators (Table 2). Functional feeding composition per sites was very similar from T1 to M3, collectorgatherers, scrapers and predators being the dominant species. In terms of relative abundance collector-gatherers and scrapers/grazers were the predominant groups at most sites (Table 3). Shredders reached $15 \%$ of the relative abundance at $\mathrm{U} 1$ but they were not abundant in the upper sites and were practically absent at middle and lower basin sites. Collector filterers were well represented in T1, T2, M3 and L2. At L1 (regulated site), the community was dominated by scrapers and collector gatherers, whereas collector filterers that comprised more than $25 \%$ of abundance at M3, were practically absent at this site (Table 3).

Scrapers/grazers had maximum density in February at $\mathrm{U} 1, \mathrm{~T} 3$ and $\mathrm{T} 4$, and were also well represented from $\mathrm{U} 3$ to L1. Collector filterers were also represented during February and peaked at T1 in May. In spite of low densities observed in samples collected in September, benthic community was mostly dominated by scrapers/grazers and collector gatherers at most sites. With the exception of T1, L2 and L3, collector gatherers dominated most samples collected in December (Fig. 5).

RDA of the FFG data accounted for 44.5 of the total variance in the FFG data with its first 2 axes (Fig. 6). The $1^{\text {st }}$ axis (eigenvalue RDA1: 0.42) was significant $(\mathrm{p}<0.001)$ and represented an environmental gradient mainly defined by altitude, substrate size, total suspended solids, and secondarily by ammonia. The $2^{\text {nd }}$ axis (eigenvalue RDA2: 0.03) represented a gradient of discharge and particulate organic material. The speciesenvironment correlations were 0.76 and 0.43 for the two $1^{\text {st }}$ axes, and unrestricted Monte Carlo permutation test indicated that all the axes were significant $(\mathrm{F}=6.01$, $\mathrm{p}<0.001$ ), showing a good relationship of FFG abundance and measured environmental variables. Scrapers/grazers present at the headwaters tributaries and upper channel sites with higher elevation and substrate size were positioned in an extreme position to the left, in an intermediate position on same axis were predators and collector filterers (Fig. 6). Shredders occurring on main upper basin sites having more POM biomass were positioned in the upper left quadrant. Most FFG showed higher densities at sites and months having low TSS contents (Fig. 6).

\section{Biotic indices and water quality}

From U3 to M1 diversity, species richness and EPT richness decreased dramatically (50\%), whereas biotic indices decreased 25-30\% (Table 3). According to the IAP scores, M1 and the regulated site L1 were the most affected sites, from T1 to U3 were very clean water, and from M1 to L2 the obtained values indicated lightly polluted waters. BMPS values were lower at most sites when comparing with the IAP values. Scores of sites in the middle and lower basin indicated probably polluted waters, and excepting by U1 and U2 most sites on rivers and tributaries in upper basin showed probably incipient pollution or other kind of perturbations. BMPS seemed to be very sensitive to sedimentation process. On the other hand, the EPT index was more sensitive to assess the effect of regulation (from M3 to L1) than the rest of used metrics. Indexes values were correlated significantly with a range of water quality variables including: nutrients, conductivity and TSS. They were also affected by altitude, substrate size, discharge and distance from the source (Table 4). 

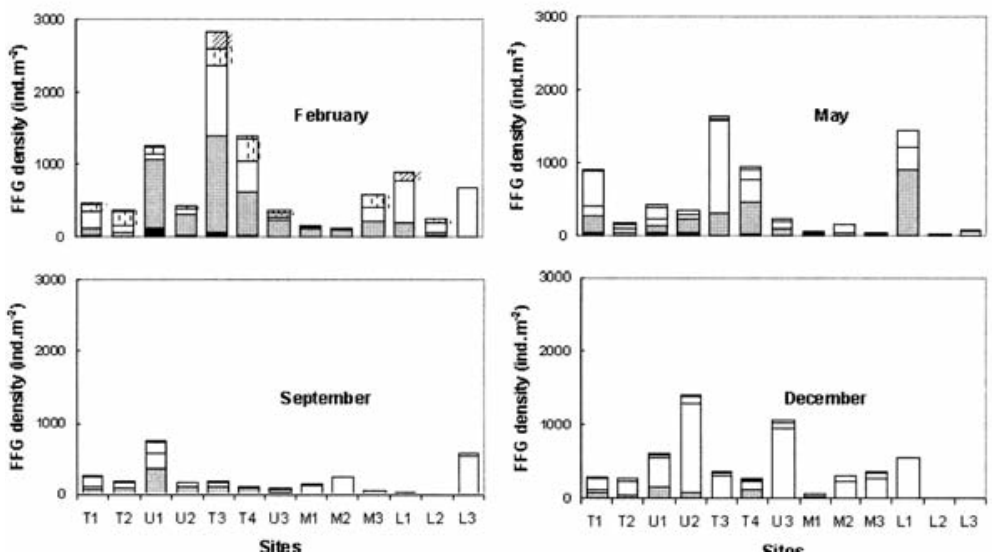

Fig. 5. Seasonal variation of functional feeding groups in riffle areas $(n=3)$ of 13 sampling sites of upper, middle and lower Chubut River basin.

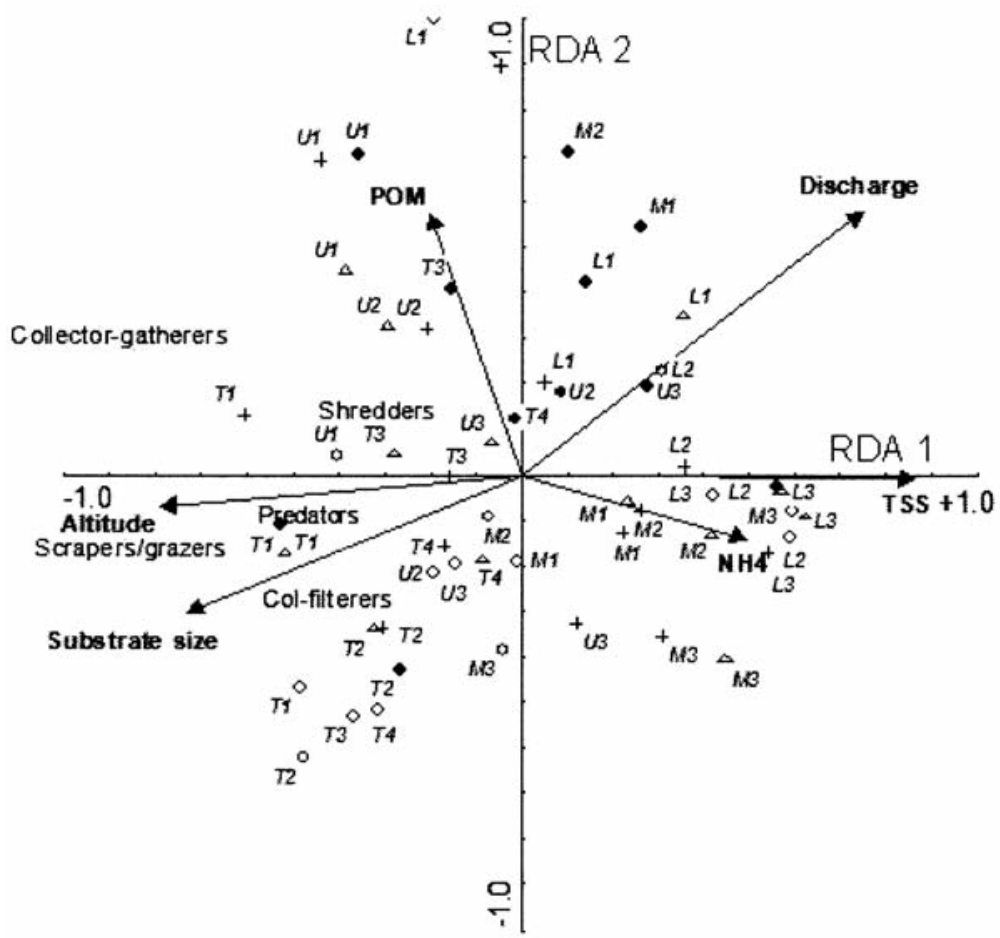

Fig. 6. Redundancy analysis triplot for functional feeding group's abundances, sites and environmental relationships at the Chubut river system. Sites codes: Open circles: February, Crosses: May, Dark circles: September and Triangles: December. 
Table 2. Relative abundance (percentages) of the functional feeding groups macroinvertebrate species in 13 sampling sites of the Chubut River Basin, Patagonia, Argentina in the study period.

\begin{tabular}{|c|c|c|c|c|c|c|c|c|c|c|c|c|c|}
\hline Taxa & T1 & T2 & U1 & U2 & T3 & T4 & U3 & M1 & M2 & M3 & L1 & L2 & L3 \\
\hline \multicolumn{14}{|l|}{ Shredders } \\
\hline Klapopteryx kuscheli Illies (Kk) & 0.03 & & & & & & & & & & & & \\
\hline Brachysetodes major Schmid (Bm) & & & 1.7 & 0.2 & 0.01 & 0.1 & 0.3 & 0.8 & & 0.03 & & & \\
\hline Parasericostoma ovale Schmid (Po) & & 0.2 & 13.6 & 5.1 & & 0.04 & 0.3 & & 0.04 & & & & \\
\hline Antarctoperla michaelseni Klapálek (Am) & 2.5 & 0.7 & 0.1 & 0.5 & 1.5 & 1.2 & & & & 0.2 & & 5.6 & \\
\hline Monocosmoecus sp (M) & & & 0.04 & & & & & & & & & & \\
\hline \multicolumn{14}{|l|}{ Scrapers/Grazers } \\
\hline Notoperla magnaspina Mc Lellan (Nm) & 0.02 & 0.2 & & & & & & & & & & & \\
\hline Notoperlopsis femina Illies (Nf) & 3.0 & 2.1 & 1.0 & 0.4 & 2.5 & 4.9 & 1.0 & & & & & & \\
\hline Limnoperla jaffueli Navás $(\mathrm{Lj})$ & 0.3 & 0.3 & 3.2 & 0.8 & 0.1 & 0.05 & & & 1.5 & & & & \\
\hline Chilenoperla semictinta Illies (Chs) & & & 0.01 & & & & & & & & & & \\
\hline Aubertoperla illiesi Illies (Ai) & 0.4 & 0.3 & 0.5 & & & & & & & & & & \\
\hline Potamoperla myrmidon Illies ( $\mathrm{Pm})$ & 0.6 & 0.2 & 0.04 & 10.5 & 0.9 & 2.6 & 12.7 & 30.4 & 14.4 & 22.4 & 0.02 & 15.0 & \\
\hline Mastigoptila longicornuta Schmid (Mlon) & & & 0.5 & 0.2 & & 0.05 & & & & 0.1 & & & \\
\hline Oxyethira bidentata Mosely $(\mathrm{Ob})$ & & & & & & & & 0.3 & & & 1.4 & & \\
\hline Metrichia neotropicalis Schmid (Mn) & & 0.1 & & 0.1 & 0.1 & 0.2 & 0.1 & & 0.04 & 0.1 & 2.7 & 0.1 & \\
\hline Podonominae sp. (Pod) & 0.2 & 0.3 & & & & & & & & & & & \\
\hline Neotrichia sp. (N) & & & 19.9 & & 0.05 & 0.02 & & 0.1 & & & & & \\
\hline Chilina sp (Chill) & & & & & & & 1.9 & & & & & & \\
\hline Chilina patagonica Sowerby (Chp) & & & 0.2 & 0.1 & 0.1 & 0.2 & 0.3 & 0.2 & 0.5 & 0.8 & 25.0 & & \\
\hline Meridialaris laminata Ulmer (MI) & 7.7 & 6.9 & 17.4 & 10.1 & 16.6 & 26.3 & 0.7 & & 0.1 & & 0.9 & 1.3 & \\
\hline Meridialaris chiloeensis Demoulin (Mc) & 10.3 & 9.6 & 1.2 & & & 2.9 & & & & & & & \\
\hline Penaphlebia chilensis Eaton $(\mathrm{Pc})$ & & & 0.01 & 0.03 & & 0.1 & 0.02 & & & & & & \\
\hline Nousia delicata Navás (Nd) & 0.02 & & & & & 6.7 & 0.1 & & & & & & \\
\hline Nousia crena Pescador \& Peters (Ncr) & & & & & 14.4 & & & & & & & & \\
\hline $\begin{array}{l}\text { Nousia bella Pescador \& Peters (Nb) } \\
\text { Gasteropoda sp. (G) }\end{array}$ & & 0.03 & & & & & & & & & & & 0.03 \\
\hline Nousia maculata Demoulin (Nma) & 1.4 & 2.9 & & & & & & & & & & & \\
\hline Lymnaea diaphana King (Ld) & & & & & 0.01 & & 0.2 & & & & 9.6 & 0.3 & \\
\hline Glundachia concentrica d'Orbigny (Gc) & & & & & & & & & & & 0.5 & & \\
\hline Austrelmis sp (Aus) & 0.2 & 0.2 & 0.1 & 0.4 & 0.1 & 0.7 & 1.2 & 0.2 & 0.3 & 0.03 & & & \\
\hline Austrolimnius spp. (Alim) & 1.0 & 1.3 & 1.1 & 2.2 & 0.1 & 2.2 & 2.2 & 0.2 & & & & & \\
\hline Luchoelmis sp (L) & & & 0.01 & 0.6 & & & 0.1 & & & & & & \\
\hline L. cekalovici Spangler \& Staines (Lc) & 2.5 & 0.2 & 0.5 & 2.2 & & & 0.3 & & & & & & \\
\hline Stethelmis kaszabi Hinton (Sk) & & & 0.1 & 0.01 & & & & & & & & & \\
\hline Hydora annectens Spangler \& Brown (Ha) & & & & & & 0.02 & 0.02 & & 0.1 & & & & \\
\hline Acari sp1 (Ac1) & & & & & & 0.01 & & & & & & & \\
\hline Acari sp2 (Ac2) & & & & & & & 0.02 & & & & & & \\
\hline \multicolumn{14}{|l|}{ Collector gatherers } \\
\hline Andesiops torrents (At) & 5.4 & 4.5 & 1.7 & 0.7 & 0.05 & 0.4 & 0.04 & 0.4 & 1.1 & 0.1 & 0.2 & 1.1 & \\
\hline Americabaetis sp. (A) & 0.1 & & 0.8 & 0.2 & 0.5 & 1.3 & 0.04 & 0.6 & 4.2 & 1.2 & 9.0 & 4.6 & \\
\hline C. penai Travers \& Edmunds (Cp) & & & & 1.0 & & & 0.5 & & & 0.03 & & & \\
\hline Caenis sp (Cae) & & 0.03 & & 1.2 & 0.9 & 0.6 & 4.8 & & 0.7 & & & & \\
\hline Traverella $\mathrm{sp}(\mathrm{Tr})$ & & & & 0.01 & & & 0.3 & 10.9 & 21.7 & 29.8 & & 37.3 & \\
\hline Paratrichocladius spl (Par 1) & 3.3 & 5.3 & 10.8 & 3.0 & 18.1 & 5.2 & 9.4 & 5.7 & 31.6 & 3.9 & 1.8 & 1.4 & \\
\hline Paratrichocladius sp2 (Par 2) & 4.8 & 19.2 & 2.9 & 40.6 & 4.8 & 6.5 & 28.8 & 29.7 & 0.5 & 10.4 & 6.6 & 2.6 & \\
\hline Cricotopus sp (Cri) & 0.03 & 0.2 & 1.6 & 0.4 & 1.6 & & & & & & & & \\
\hline Thiennemanella sp (Thi) & 0.2 & 0.1 & 1.1 & 0.3 & & 1.0 & 0.2 & 0.2 & & & & & \\
\hline
\end{tabular}




\begin{tabular}{|c|c|c|c|c|c|c|c|c|c|c|c|c|c|}
\hline Taxa & T1 & T2 & U1 & $\mathrm{U} 2$ & T3 & $\mathrm{T} 4$ & U3 & M1 & M2 & M3 & L1 & L2 & L3 \\
\hline Lopescladius sp (Lo) & & & & & & & & & & 0.03 & & & 0.03 \\
\hline Pseudosmittia sp (Ps) & 3.5 & 2.4 & 0.3 & 0.4 & 0.1 & 0.9 & 0.5 & 0.2 & & & 3.3 & 2.0 & \\
\hline Parametriocnemus sp (Paps) & 0.3 & 0.03 & & 1.8 & 2.0 & 6.6 & 1.8 & 0.2 & 0.04 & 0.1 & & 0.4 & \\
\hline Orthocladinae sp (Ort) & & & 0.1 & & 0.1 & & & 1.4 & & & 17.1 & & \\
\hline Orthocladiinae spl (Ort1) & 0.5 & 3.0 & 1.0 & & 0.2 & & & & & & & & \\
\hline Orthocladiinae sp2 (Ort2) & 0.02 & 0.4 & 0.6 & 0.6 & 0.2 & 0.2 & 0.04 & & & & & & \\
\hline Orthocladiinae sp3 (Ort3) & & & & & & & & 0.2 & & & & & \\
\hline Orthocladiinae sp4 (Ort4) & & 2.8 & & 6.4 & & & 10.9 & & 0.5 & & & & \\
\hline Polypedilum sp (Pol) & & & & & & & & & 0.1 & 0.5 & 0.1 & & \\
\hline Parachironomus sp (Parch) & & & 1.0 & 0.1 & & & & & & & & & \\
\hline Tribelos sp (Tri) & & & & & 0.1 & & & 0.5 & & & & & \\
\hline Dicrotendipes sp (Dicr) & & & & & & 0.05 & 0.2 & & & & & & \\
\hline Lumbriculus variegatus Müller (Lv) & 3.0 & 1.4 & 2.1 & 1.6 & 0.2 & 0.9 & 7.0 & 0.8 & 2.5 & 3.1 & & 0.8 & \\
\hline Limnodrilus sp. (Limn) & & & & 0.2 & & 0.1 & & 0.5 & 9.6 & & 1.3 & 0.3 & 97.5 \\
\hline Nais communis Piguet (Ncom) & & & & & 22.7 & 7.2 & & & & & 7.3 & & \\
\hline Phreodrilus sp. (Phr) & & & & & & & & & & & 0.7 & & \\
\hline Hyalella curvispina Shoemaker (Hc) & & & & 0.01 & 0.01 & 0.01 & & & & & 0.05 & 0.3 & \\
\hline \multicolumn{14}{|l|}{ Collector-filterers } \\
\hline Smicridea annulicornis Blanchard (Sa) & 27.8 & 22.3 & & 0.9 & 3.5 & 16.1 & 1.7 & & & & & & \\
\hline S. frequens Navás (S) & & & 1.6 & & & & 1.7 & & & & & 12.7 & \\
\hline S. dithyra Flint (Sd) & & & & & & & & 0.6 & 1.1 & 4.2 & & 10.5 & \\
\hline Smicridea sp (Smi) & 3.1 & 1.9 & & & & & & & & & & & \\
\hline Rheotanytarsus sp (Rhe) & 0.2 & 0.3 & 0.04 & 3.6 & 1.8 & 0.5 & 4.0 & & & 0.1 & & 0.7 & \\
\hline Simulium sp. (Sim) & 12.3 & 2.5 & 9.8 & 0.5 & 0.4 & 0.5 & 0.9 & 14.2 & 7.8 & 21.7 & 0.1 & 1.1 & \\
\hline \multicolumn{14}{|l|}{ Predators } \\
\hline Kempnyela genualis Navás (Kg) & & & 0.01 & & & & & & & & & & \\
\hline Chiloporter eatoni Lestage (Che) & & & 0.1 & & & & & & & & & & \\
\hline Cailloma sp. (C) & 0.4 & 0.1 & 0.1 & 0.1 & 0.01 & & & & & & & & \\
\hline Neoatopsyche chilensis Schmid (Nc) & 0.02 & 0.3 & 0.2 & 0.04 & 0.4 & 0.4 & & & & & & & \\
\hline Amphichorema sp. (Amp) & & & 0.03 & & & & & & & & & & \\
\hline $\begin{array}{l}\text { Neopsylochorema tricarinatum Schmid (Nt) } \\
\text { Crypotochironomus sp (Crip) }\end{array}$ & 0.1 & 0.8 & 1.7 & 0.03 & 0.5 & 0.01 & & & & & & & \\
\hline Tanypodinae sp (Tan) & 1.3 & 2.7 & 0.7 & 0.9 & 3.8 & 1.1 & 1.1 & 0.7 & 0.9 & 0.9 & 0.3 & 0.6 & \\
\hline Hexatoma sp. (Hex) & 2.6 & 3.3 & 0.3 & 0.4 & 0.8 & 0.3 & 0.3 & & 0.1 & & & & \\
\hline Limnophila sp.(Lim) & & & & 0.03 & & & & & & & & & \\
\hline Molophilus sp. (Mol) & & & & & & & & & & & 0.01 & & \\
\hline Dasyoma sp. (Das) & 0.5 & 0.4 & 0.04 & 0.01 & 0.1 & 0.1 & 1.6 & & & & & & \\
\hline Empididae sp (Emp) & 0.3 & 0.2 & 0.2 & 0.2 & 0.01 & 0.1 & 1.0 & 0.7 & 0.2 & & 0.1 & & \\
\hline Lispoides sp. (Mus) & 0.02 & 0.2 & & & 0.3 & 0.1 & & & 0.4 & 0.03 & & & \\
\hline Ceratopogonidae (Cer) & 0.02 & 0.2 & 0.1 & 0.4 & & & & & & & & & \\
\hline Tabanidae sp (Tab) & 0.03 & & & 0.4 & & 0.04 & 0.3 & 0.2 & 0.1 & & & & \\
\hline Psychodidae sp (Psy) & & & & 0.01 & & 0.01 & & & & & 0.02 & & \\
\hline Glossiphonidae sp1 (Glo) & & & 0.1 & 0.01 & & & & & & & 0.6 & & \\
\hline Glossiphonidae sp2 (Glo2) & & & & & & & 0.1 & & & & & & \\
\hline Girardia sp. (Gir) & & & & 0.1 & 0.02 & 0.1 & 0.2 & 0.2 & & 0.03 & 11.3 & 0.4 & \\
\hline Temnocephalidae sp. (Tem) & & & & & & 0.05 & & & & & & & \\
\hline Hemiosus dejeani Solier (Hd) & & & 0.01 & 0.8 & 0.4 & 1.2 & 0.9 & & & & & & \\
\hline Andogyrus seriatopunctatus Régimbart (As) & & & 0.01 & & & & & & & & & & \\
\hline Aegla sp & & & 0.01 & 0.1 & & 0.1 & 0.02 & & 0.1 & 0.1 & & 0.8 & \\
\hline Decapoda & & & & & & & & & & & & & 2.4 \\
\hline Nereis sp. (Ner) & & & & & & & & & & & & & 0.1 \\
\hline
\end{tabular}


Table 3. Cumulative richness, relative abundance (percentages) of functional feeding groups, mean annual value ( \pm SD) of biotic indices and diversity measured on riffles $(n=12)$ of 13 sampling sites on the Chubut River Basin during the study period (EPT: Ephemeroptera, Plecoptera and Trichoptera species richness, IAP: Indice Andino Patagónico, BMPS: Biotic Monitoring Patagonian Streams).

\begin{tabular}{|c|c|c|c|c|c|c|c|c|c|c|c|c|c|}
\hline & $\mathrm{T} 1$ & $\mathrm{~T} 2$ & U1 & $\mathrm{U} 2$ & T3 & T4 & U3 & M1 & M2 & M3 & L1 & L2 & L3 \\
\hline \multicolumn{14}{|l|}{ FFG richness } \\
\hline Shredders & 2 & 2 & 4 & 3 & 2 & 3 & 2 & 1 & 1 & 2 & 0 & 1 & 0 \\
\hline Scrapers/grazers & 12 & 13 & 16 & 13 & 11 & 15 & 15 & 6 & 7 & 5 & 7 & 4 & 1 \\
\hline Collector gatherers & 12 & 13 & 12 & 17 & 15 & 14 & 14 & 13 & 11 & 10 & 11 & 10 & 2 \\
\hline Collector filterers & 4 & 4 & 3 & 3 & 3 & 3 & 4 & 2 & 2 & 3 & 1 & 4 & 0 \\
\hline Predators & 10 & 9 & 15 & 15 & 10 & 13 & 9 & 4 & 6 & 4 & 6 & 3 & 1 \\
\hline \multicolumn{14}{|l|}{ FFG relative abundance } \\
\hline Shredders & 2.53 & 0.9 & 15.44 & 5.8 & 1.51 & 1.34 & 0.6 & 0.8 & 0.04 & 0.23 & 0 & 5.6 & 0 \\
\hline Scrapers/grazers & 27.44 & 24.33 & 45.77 & 27.64 & 34.96 & 46.95 & 20.86 & 31.4 & 16.94 & 23.43 & 40.12 & 16.7 & 0.03 \\
\hline Collector gatherers & 21.15 & 39.36 & 24 & 58.52 & 51.56 & 30.96 & 64.52 & 51.3 & 72.54 & 49.16 & 47.45 & 50.8 & 97.53 \\
\hline Collector filterers & 43.4 & 27 & 11.44 & 5 & 5.7 & 17.1 & 8.3 & 14.8 & 8.9 & 26 & 0.1 & 25 & 0 \\
\hline Predators & 5.29 & 8.2 & 3.61 & 3.53 & 6.34 & 3.61 & 5.52 & 1.8 & 1.8 & 1.06 & 12.33 & 1.8 & 2.4 \\
\hline \multicolumn{14}{|l|}{ Indexes } \\
\hline H'(Shannon-Weaver) & $\begin{array}{l}2.97 \\
(0.5)\end{array}$ & $\begin{array}{l}2.86 \\
(0.7)\end{array}$ & $\begin{array}{l}3.07 \\
(0.4)\end{array}$ & $\begin{array}{l}2.79 \\
(0.7)\end{array}$ & $\begin{array}{c}2.2 \\
(0.5)\end{array}$ & $\begin{array}{l}2.81 \\
(0.7)\end{array}$ & $\begin{array}{l}3.01 \\
(0.6)\end{array}$ & $\begin{array}{l}1.67 \\
(0.5)\end{array}$ & $\begin{array}{l}1.54 \\
(0.9)\end{array}$ & $\begin{array}{l}2.05 \\
(0.4)\end{array}$ & $\begin{array}{c}1.89 \\
(1)\end{array}$ & $\begin{array}{l}2.66 \\
(0.4)\end{array}$ & $\begin{array}{l}0.34 \\
(0.2)\end{array}$ \\
\hline Mean species richness & $\begin{array}{r}23.75 \\
(3.1)\end{array}$ & $\begin{array}{l}23.5 \\
(3.7)\end{array}$ & $\begin{array}{c}29 \\
(2.7)\end{array}$ & $\begin{array}{c}27 \\
(5.4)\end{array}$ & $\begin{array}{l}22.5 \\
(3.3)\end{array}$ & $\begin{array}{c}26.75 \\
(7.1)\end{array}$ & $\begin{array}{l}23.5 \\
(2.4)\end{array}$ & $\begin{array}{l}12.5 \\
(3.1)\end{array}$ & $\begin{array}{c}13 \\
(5.1)\end{array}$ & $\begin{array}{l}12.25 \\
(4.2)\end{array}$ & $\begin{array}{l}13.5 \\
(3.4)\end{array}$ & $\begin{array}{l}11.25 \\
(4.9)\end{array}$ & $\begin{array}{c}2.5 \\
(1.7)\end{array}$ \\
\hline EPT richness & $\begin{array}{c}10 \\
(2.2)\end{array}$ & $\begin{array}{l}10.5 \\
(3.8)\end{array}$ & $\begin{array}{l}13.5 \\
(1.9)\end{array}$ & $\begin{array}{l}10.75 \\
(2.9)\end{array}$ & $\begin{array}{c}8.5 \\
(2.1)\end{array}$ & $\begin{array}{l}10.5 \\
(3.7)\end{array}$ & $\begin{array}{c}8 \\
(2.2)\end{array}$ & $\begin{array}{c}4.5 \\
(1.7)\end{array}$ & $\begin{array}{l}5.75 \\
(1.9)\end{array}$ & $\begin{array}{c}5 \\
(2.1)\end{array}$ & $\begin{array}{c}3 \\
(0.8)\end{array}$ & $\begin{array}{l}5.25 \\
(2.7)\end{array}$ & 0 \\
\hline IAP & $\begin{array}{c}9.5 \\
(0.6)\end{array}$ & $\begin{array}{c}9.5 \\
(0.6)\end{array}$ & $\begin{array}{l}10 \\
(0)\end{array}$ & $\begin{array}{l}9.75 \\
(0.5)\end{array}$ & $\begin{array}{c}9 \\
(1.4)\end{array}$ & $\begin{array}{l}9.5 \\
(0.6)\end{array}$ & $\begin{array}{l}9.25 \\
(0.9)\end{array}$ & $\begin{array}{l}6.75 \\
(1.2)\end{array}$ & $\begin{array}{c}7.5 \\
(1.2)\end{array}$ & $\begin{array}{l}7.5 \\
\text { (1) }\end{array}$ & $\begin{array}{l}6.75 \\
(0.5)\end{array}$ & $\begin{array}{c}7.5 \\
(1.9)\end{array}$ & $\begin{array}{l}1.75 \\
(0.5)\end{array}$ \\
\hline BMPS & $\begin{array}{l}75.75 \\
(7.9)\end{array}$ & $\begin{array}{l}73.5 \\
(14)\end{array}$ & $\begin{array}{l}106.5 \\
(9.1)\end{array}$ & $\begin{array}{l}104.25 \\
(17.6)\end{array}$ & $\begin{array}{l}79.75 \\
(15.9)\end{array}$ & $\begin{array}{c}92 \\
(12)\end{array}$ & $\begin{array}{c}84.5 \\
(14.4)\end{array}$ & $\begin{array}{c}50.5 \\
(13.8)\end{array}$ & $\begin{array}{c}51.5 \\
(21.9)\end{array}$ & $\begin{array}{c}49 \\
(8.2)\end{array}$ & $\begin{array}{c}45 \\
(11.6)\end{array}$ & $\begin{array}{l}43.75 \\
(14.4)\end{array}$ & $\begin{array}{l}7.75 \\
(7.2)\end{array}$ \\
\hline
\end{tabular}

Table 4. Significant Pearson product-moment correlation $(\mathrm{p}<0.05)$ after Bonferroni adjustment among biotic indexes and environmental variables $(n=52)$. Dist: distance from the source, Disch: discharge, Alt: altitude, Chlor: chlorophyll a, SS: substrate size, SO: stream order

\begin{tabular}{|c|c|c|}
\hline \multirow[t]{2}{*}{ Index } & \multicolumn{2}{|c|}{ Relationship } \\
\hline & Positive (+) & Negative $(-)$ \\
\hline IAP & Alt, SS & $\begin{array}{c}\mathrm{K}_{20}, \mathrm{TA}, \mathrm{TSS}, \mathrm{NH}_{4}, \mathrm{NT} \text { SRP, } \\
\text { TP, Chlor, SO, Disch, Dist }\end{array}$ \\
\hline EPT & Alt, SS & $\begin{array}{l}\mathrm{K}_{20}, \mathrm{TA}, \mathrm{TSS}, \mathrm{NH}_{4}, \mathrm{NT} \text { SRP, } \\
\text { TP, SO, Disch, Dist }\end{array}$ \\
\hline $\mathrm{H}$ & Alt, SS & $\mathrm{K}_{20}, \underset{\text { DSS, }}{\mathrm{NH}_{4}, \mathrm{SRP}, \mathrm{TP}} \mathrm{SO}$, \\
\hline SR & Alt, SS & $\begin{array}{l}\mathrm{K}_{20}, \mathrm{TA}, \mathrm{TSS}, \mathrm{NH}_{4}, \mathrm{NT} \\
\text { SRP, TP, SO, Disch, Dist }\end{array}$ \\
\hline BMPS & Alt, SS & $\begin{array}{l}\mathrm{K}_{20}, \mathrm{TA}, \mathrm{TSS}, \mathrm{NH}_{4}, \mathrm{NT} \\
\text { SRP, TP, SO, Disch, Dist }\end{array}$ \\
\hline
\end{tabular}

\section{Discussion}

This is the first study on large arid rivers in Patagonia examining benthos functional structure in a longitudinal gradient. In terms of functional feeding group's distribution, benthos community showed few changes across the longitudinal gradient, collectors (gatherer and filterers) being the dominant functional group at most sites. However, if we exclude tributaries in the analysis, collector gatherers relative abundance increased from U1 to M2 main channel sites, which is quite consistent with RCC predictions (Vanotte et al. 1980). In addition, RDA ordination showed that shredders were slightly more abundant in the upper basin main channel sites than in the sites on middle basin having low POM availability, whereas collector filterers were represented at several sites of the river indicating the importance of seston transport in the water column (Minshall et al. 1992, Palmer et al. 1996). The significance of fine detritus as food resources for macroinvertebrates has been recently remarked by Tomanova et al. (2006) in other South American lotic ecosystems. The fact that the collector filterers (Hydropsychidae, Simulidae) were abundant at upper basin tributaries (T1 and T2) responded to a significant habitat complexity that possibly enhanced organic matter retentions and availability of suspended organic matter. Similar observations have been reported by Bis et al. (2000) and Townsend et al. (1997) in native forest streams. The absence of collector-filterers right below the impoundment could be related with the discontinuities in seston supply below large impounded rivers (Troesltrup \& Hergenrader 1990). In the Chubut river post dam site, scrapers augmented in relative abundance (two fold) possibly after an increase of water transparency that enhanced algal productivity (Ward \& Stanford 1994), whereas more tolerant predators (mostly flatworms) also increased significantly. 
Seasonal assessment showed higher scrapers/grazers abundance in February and May than the other months at most sites in the system, consistent with a reduced discharge, higher temperature and an increase in illumination that favored primary production. On the contrary, dominance of the collector gatherers on December responded to unstable conditions (Minshall et al. 1992). Late spring had warm temperatures but still the river showed high discharge, discharge values on December doubled those recorded in February.

As reported for large rivers in arid continental zones (Reece \& Richardson 2000) middle basin sites showed a community with low density, poorly structured, which may be due to low resources, shifting substrates and high levels of suspended particles. Benthic community structure on semiarid streams in Portugal was associated with low stability and high resilience, with species having strong capacity to recolonize streams subject to flood of high magnitude, or inversely, impacted by drought (Cortes et al. 2002).

Particulate organic matter was higher than expected considering that most sites were open canopied and a great part of the Chubut basin drains the herbaceous shrub-like steppe. POM values were comparable to those found for forested stream at similar latitude in the North Hemisphere (Rempel et al. 1999, González et al. 2003) but lower to observed in a six order river in Germany (Wanner et al. 2002). Contrasting with reported for forested streams, POM was significantly lower in summer than other seasons (Velásquez \& Miserendino 2003, Mollá et al. 2006). In large semiarid systems with variable flow regime, large amount of organic matter is often incorporated after lateral interaction which results in high carbon source (Francis \& Sheldon 2002). Following an unusual expansion of the river produced by continual rains in winter, abundant debris including trees dislodged from the river corridor was observed at several main channel sites in the Chubut River. Biophysical attributes of rivers in arid and semi-arid regions seems to differ strongly from those in mesic regions, river floods appear to create heterogeneity in the establishment of woody debris piles which can has long term influence within the macrochannel (Pettit et al. 2006).

In the Chubut River distance from the source was a good predictor of POM biomass. As explained by Johnson \& Covich's (1997) distance downstream is the large-scale control, riparian forest cover the mesoscale control and retention the fine-scale mechanism regulating detritus distribution. Roeding \& Smock's (1989) confirmed that the abundance of debris dams significantly determined not only higher retention of the river, providing energetic stability in river dynamics, but also affected the temporal and spatial distribution of shredding macroinvertebrates. In my study, though local discontinuities in the POM distribution (M3 vs. L1) were clearly detected this not necessarily resulted in an increase of shredders at M3. Instead collector-filterers abundance was higher and predators abundance lower at M3 than L1. As I mentioned, this shift in the benthic community structure was possibly explained by other factors related with the presence of the dam.

All macroinvertebrate samples could be consider comparable since were taken on riffles areas. As suggested by Beauger et al. (2006) rapid bioassessment programs should be carried out in mineral substrates in unit riffles where richness is high and density sufficient represented macroinvertebrate community including pollution sensitive taxa. The present study was not optimal since could not include oxygen content and biochemical oxygen demand data. Nevertheless, all indexes were relatively sensitive to increases of nutrients enrichment, conductivity and turbidity (Growns et al. 1995, Pizzolón \& Miserendino 2001) and responded positively with altitude and substrate size (Lang \& Reymond 1995, Chessman et al. 1997).

In the middle basin area where land use is typically rural the most sensitive metrics to physical disturbances (primarily desertification and erosion processes) were Shannon Weaver, species richness and EPT richness. Similar results have been found by Silveira et al, (2005) in neotropical rivers suffering land cover degradation. BMPS scores showed low values even in upper basin tributaries, and in middle and lower basin sites were also very low. In previous studies in the Patagonia Mountain, the BMPS resulted in reduced scores in sites with high sedimentation or with deforestation in early stages (Pizzolón \& Miserendino 2001).

It is difficult to conclude if the changes observed in metrics were due to degradation or if we were observing a natural pattern of distribution of macroinvertebrate species in a river draining an arid area. There was a reasonable change in the physicochemical conditions and indexes seemed to respond to these changes. However, since this is the first intensive study on benthic structure in a river from the Plateau; we do not have other river of reference with which to compare. It will be advisable to develop more studies in large rivers draining through the Patagonian Plateau. Until that happens, the outcomes presented in this paper referred to water quality and biotic indexes should be considered carefully. 


\section{Acknowledgements}

This study was partially supported by CONICET (Res. 649), Project A.W.A.R.E. Foundation (P-000537) and the Dirección General de Protección Ambiental de la Provincia de Chubut. Special thanks to C. Di Prinzio, E. Hollman and C. Masi and R. Suárez for fieldtrip assistance. Ing. Pablo Rimoldi (INTA) provided agricultural and cattle live stock data. Discharge data were provided by the Sistema Nacional de Información Hídrica de la Subsecretaría de Recursos Hídricos. I thank two anonymous reviewers for valuable observations that greatly improved the manuscript. This is Scientific Contribution $n^{\circ} 16$ from LIESA.

\section{References}

Allan D.J. 1995. - Stream Ecology. Structure and function of running waters. Chapman \& Hall. London-New York. 388 pp.

American Public Health Association. 1994. - Standard Methods for the examination of water and wastewater. American Water Works Association, Hanover, Maryland USA.

Ardolino A., Franchi M., Remesal M. \& Salani F. 1999. - El volcanismo en la Patagonia Extrandina. pages 579-612. In: Geología Argentina, Caminos R. (ed), Instituto de Geología y Recursos Minerales. Buenos Aires.

Armitage PD. 1984. - Environmental changes induced by stream regulation and their effects in lotic macroinvertebrate communities. pages 139-165. In: Regulated Rivers. Lillehammer, A. and Saltveit, S.J. (eds.), Oslo University Press, Oslo.

Beauger A., Lair N., Reyes-Marchant P. \& Peiry J.L. 2006. The distribution of macroinvertebrate assemblages in a reach of the River Allier (France), in relation to riverbed characteristics. Hydrobiologia, 571, 63-76.

Bis B., Zdanowicz A. \& Zalewski M. 2000. - Effect of catchment properties on hydrochemistry, habitat complexity and invertebrate community structure in a lowland river. Hydrobiologia, 422/423, 369-387.

Bretschko G. 1995. - River/land ecotones: scales and patterns. Hydrobiologia, 303, 83-91.

Chessman B. C., Growns J. E. \& Kotlash A. R. 1997. - Objective derivation of macroinvertebrate family sensitivity grade numbers for the signal biotic index: application to the hunter river system, New South Wales. Mar. Freshwater Res., 48, 159-172.

Coronato F.R. \& del Valle H.F. 1988. - Caracterización hídrica de las cuencas hidrográficas de la provincia del Chubut. Cenpat. Conicet, Puerto Madryn, Chubut, Argentina. 288 pp.

Cortes R.M., Ferreira V., Oliveira M.T., Oliveira D. 2002. - Macroinvertebrate community structure in a regulated river segment with different flow conditions. River Res. App., 18, 367-382.

Cummins K. W., Wilzbach M.A, Gates D.M., Perry J.B. \& Taliaferro W.B. 1989. - Shredders and riparian vegetation. Bioscience, 39, 25-30.

del Valle H.F., Elissalde N.O., Gagliardini D.A., Milovich J. 1998. Status of desertification in the Patagonian region: Assessment and mapping from satellite imagery. Arid Soil Res. Rehab., 12, 1-27.

del Valle HF, Labraga JC, Goergen J. 1995. - Biozonas de la Región Patagónica. Pages: 37-55, In: Evaluación del Estado Actual de la desertificación en Areas representativas de la Patagonia: Informe Final de la etapa I. Edited by INTA-GTZ, Río Gallegos-TrelewPuerto Madryn-Bariloche.

Domínguez E. 1998. - Ephemeroptera. Pages: 7-13, In Morrone J.J. y S. Coscarón (eds.). Biodiversidad de artrópodos argentinos una perspectiva biotaxonómica. Ediciones Sur. La Plata. Argentina. 599 pp.

Fernández H.R. \& Domínguez E. 2001. - Guía para la determinación de los Artrópodos bentónicos sudamericanos. EUDET. Tucumán, Argentina. 282 pp.
Francis C. \& Sheldon F. 2002. - River red gum (Eucalyptus camadulensis Dehnh.) organic matter as a carbon source in the lower Darling River, Australia. Hydrobiologia 481, 113-124.

González J.M., Basaguren A. \& Pozo J. 2003. - Macroinvertebrate communities along a third order Iberian stream. Ann. Limnol., 39, 287-296.

Gordon N.D., McMahon T.A. \& Finlayson B.L. 1994. - Stream hydrology, an introduction for ecologists. Wiley and Sons, New York. $526 \mathrm{pp}$.

Growns J.E., Chessman P., Mc Evoy P.K \& Wright I. A. 1995. Rapid assessment of rivers using macroinvertebrates case studies in the Nepean River and Blue Mountains, NSW. Aust J. Ecol., 20, 130-141.

Hauer F.R. \& Resh V.H. 1996. - Benthic macroinvertebrates. pages: 339-369, In: Methods in stream ecology. Hauer F.R. \& Lamberti G.A. (eds). Academic press, San Diego, California.

Johnson, S.L. \& Covich A.P. 1997. - Scales of observation of riparian forest and distribution of suspended detritus in a prairie river. Freshwat. Biol., 37, 193-208.

Lang C. \& Reymond O. 1995. - An improved index of environmental quality for Swiss rivers based in benthic macroinvertebrates. Aquat. Sci., 57, 172-180

Lopretto E.C. \& Tell G. 1995. Ecosistemas de aguas continentales. Ed. Hemisferio Sur, La Plata. 1400 pp.

Luque J.L., Rimoldi P.O., Amari M.E. \& Berwyn A.A. 2000 . - Características edáficas de un valle natural de la meseta patagónica para la implementación del riego (Valle Medio del río Chubut). Technical report. INTA. Chubut. Argentina. 6 pp.

Merrit, R. W. \& Cummins K. W. 1996. - An introduction to the aquatic insects of North America. Kendal Hunt Publishing Co. 862 pp.

Minshall G.W., Petersen, R. C. \& Bott, T. L. 1992. - Stream ecosystem dynamics of the Salmon River, Idaho: an 8th order system. J. N. Am. Benthol. Soc., 11, 111-137

Miserendino M.L. 2004. - Effects of landscape and desertification on the macroinvertebrate assemblages of rivers in Andean Patagonia. Arch. Hydrobiol., 159 (2), 185-209.

Miserendino M.L. 2006. - Seasonal and spatial distribution of stoneflies in the Chubut River (Patagonia, Argentina). Hydrobiologia, 568, 263-274.

Miserendino M.L. \& Pizzolón L.A. 1999. - Rapid assessment of river water quality using macroinvertebrates: a family level biotic index for the Patagonic Andean zone. Acta Limnol. Bras., 11(2), 137-148.

Miserendino M.L. \& Pizzolón L.A. 2000. - Macroinvertebrates of a fluvial system in Patagonia: altitudinal zonation and functional structure. Arch. Hydrobiol, 150, 55-83.

Miserendino M.L. \& Pizzolón L.A. 2003. - Distribution of macroinvertebrate assemblages in the Azul-Quemquemtreu river basin, Patagonia, Argentina. New Zeal. J. Mar. Fresh., 37, 525-539.

Miserendino M.L. \& Pizzolón L.A. 2004. - Interactive effects of basin features and land use change on macroinvertebrate communities of headwater streams in the Patagonian Andes. River Res. App., 20, 967-982.

Molla S., Robles S. \& Casado C. 2006. - Seasonal variability of particulate organic matter in a Mountain Stream in Central Spain. Internat. Rev. Hydrobiol., 91, 406-422.

Palmer C., Maart B., Palmer A. \& O'Keefe J. 1996. - An assessment of macroinvertebrate functional feeding groups as water quality indicators in the Buffalo River, eastern Cape Province, South Africa. Hydrobiologia, 318, 153-168.

Paruelo J.M., Jobbagy E.G. \& Sala O.E. 1999. - Biozones of Patagonia (Argentina). Ecología Austral. 8. 170-178. 
Pettit N. E., Latterell J.J. \& Naiman R.J. 2006. - Formation, distribution and ecological consequences of floss-related wood debris piles in a bedrock confined river in semi-arid South Africa. River Res. App., 22, 1097-1110.

Pizzolon L.A. \& Miserendino M.L. 2001. - The performance of two regional biotic indices for running water quality in Northern Patagonian Andes. Acta Limnol. Bras., 13(1),11-27.

Poff N.L. \& Ward J.V. 1990. - Physical habitat template of lotic systems: recovery in the context of historical patterns of spatiotemporal heterogeneity. Environ. Manage., 14, 629-645.

Reece P.F. \& Richardson J.S. 2000. - Benthic macroinvertebrate assemblages of coastal and continental streams and large rivers of southwestern British Columbia Canada. Hydrobiologia , 439, 77-89.

Rempel L.L., Richardson J.S. \& Healey M. C. 1999. - Flow refugia for benthic macroinvertebrates during flooding of a large river. J.N. Am Benthol. Soc., 18(1), 34-48.

Roeding C.E. \& Smock L.A. 1989. - Ecology of macroinvertebrate shredders in a low gradient sandy bottomed stream. J. N. AM. Benthol. Soc., 8, 149-161.

Sastre A.V., Santinelli N.H., Otaño S.H. \& Ivanisevich M.E. 1997. Water quality in the lower section of the Chubut River, Patagonia, Argentina. Verh. Internat. Verein. Limnol., 26, 951-955.

Silveira M.P., Baptista D.F., Buss D.F., Nessimian J.L. \& Egler M. 2005. - Application of biological measures for stream integrity assessment in South-East Brazil. Environ. Monit. Assess., 101, 117-128.

Sokal R. R. \& Rohlf F.J. 1995. - Biometry. 3rd edition.W.H. Freeman and Company: New York. 859 pp.

Stevens L.E., Shannon J.P. \& Blinn D.W. 1997. - Colorado River benthic ecology in Grand Canyon Arizona, USA: dam, tributary and geomorphological influences. Reg. Riv. Res. \& Manag., 13, 129-149.

Tell G., Izaguirre I. \& Quintana R. 1997. - Flora y Fauna Patagónicas. Ediciones Caleuche. Bariloche, Argentina. 175 pp.

ter Braak, C. J. F. 1998. - CANOCO. A Fortran program for canonical community ordination. (partial) (detrended) (canonical) correspondence analysis principal components analysis and redundancy analysis. (version 4.0) Centre for biometry Wageningen. Wageningen. The Netherlands. ter Braak, C. J. F. \& Smilauer P. 1998. - CANOCO Reference manual and User's guide to Canoco for Windows: software for Canonical Community Ordination (version 4). Microcomputer power. (Ithaca, NY, USA)

Tomanova S., Goitia E. \& Helesic J. 2006. - Trophic levels and functional feeding groups of macroinvertebrates in neotropical streams. Hydrobiologia, 556, 251-264.

Townsend C. R., Arbuckle Ch. J, Crowl T.A. \& Scarbrook, R. 1997. - The relationship between land use and physicochemistry, food resources and macroinvertebrate communities in tributaries of the Taieri River, New Zealand: a hierarchically scaled approach. Freshwat. Biol., 37, 177-192.

Troelstrup N. H. \& Hergenrader G. L. 1990. - Effect of hydropower peaking flow fluctuations on community structure and feeding guilds of invertebrates colonizing artificial substrates in a large impounded river. Hydrobiologia, 199, 217-228.

Vanotte R. L., Minshall, G. W., Cummins, K. W., Sedell, J. R. \& Cushing, C. E., 1980. - The river continuum concept. Can. J. Fish. Aquat. Sci., 37, 130-137.

Velásquez S. M. \& Miserendino M. L. 2003. - Análisis de la materia orgánica alóctona y organización funcional de macroinvertebrados en relación con el tipo de hábitat en ríos de montaña de Patagonia. Ecologia Austral, 13, 67-82

Voelz N.J. \& Ward J. 1990. - Macroinvertebrate responses along a complex regulated stream environmental gradient. - Reg. Riv. Res. Manag., 5, 365-374

Wais IR. 1990. - A checklist of the benthic macroinvertebrates of the Negro River Basin, Patagonia, Argentina, including an approach to their functional feeding groups. Acta Limnol. Bras., 3, 829-845.

Wanner S.C., Ockenfeld K., Brunke M., Fisher H. \& Push M. 2002. - The distribution and turnover of benthic organic matter in a lowland river: influence of hydrology, seston load and impoundment. River Res. App., 18, 102-122.

Ward J.V. 1992. - Aquatic insect ecology. John Wiley \& Sons, Inc. New York-London. 438 pp.

Ward J.V. \& Stanford J.A. 1994. - The serial discontinuity concept extending the model to floodplain rivers. Reg. Riv. Res. \& Manag., 10, 159-168.

Wetzel R.G. \& Likens G.E. 1991. - Limnological analysis 2nd ed. Springer Verlang, New York. 1300 pp. 